\title{
FINANCIAL PROBLEMS AS ONE OF THE POSSIBLE REASONS OF SOCIAL EXCLUSION OF PERSONS RELEASED FROM INCARCERATION
}

\author{
Tereza Raszková, Stanislava Hoferková
}

\begin{abstract}
The paper deals with financial issues associated with imprisonment which may be one of the causes of social exclusion of persons released from prison. The authors of the contribution briefly characterize the prison system in the Czech Republic. They describe the negative effects associated with imprisonment which may lead to social problems and social exclusion. They address the potential financial problems associated with imprisonment more specifically, not only describing the reasons why imprisonment is costly for the individuals and their families but also pointing out the fact that imprisonment without probation is a financial burden for the state. They highlight the benefits of alternative punishments not connected with imprisonment of individuals and the necessity to focus on the issue of employing the persons released from prison.
\end{abstract}

\section{Keywords}

imprisonment, social exclusion, negative phenomena, financial problems, post-penitentiary care, alternatives to imprisonment

\section{Introduction}

An adequate punishment for a committed offence mainly functions as retribution and fulfilment of other purposes. Through imprisonment, we especially protect the society from the offender, but we also try to re-socialize and re-educate the perpetrators and lead them to an orderly life after their release, affecting at the same time the education of other members of society. The Czech society is traditionally very much punitively oriented. A survey of the Institute for Criminology and Social Prevention (Scheinost, 2013) confirmed that a majority of the public consider the penalties prescribed in the Penal Code as too moderate and they also perceive the sentences declared in Czech court practice as such. Conversely, some experts (e.g. Černíková, 2008) highlight the limits of the society in re-socialization and redress of some offenders. Especially the unsuspended incarceration sentence service involves "many negative phenomena which damage the 
actual perpetrators but may directly or indirectly become a burden for the whole society as well." One of these negative phenomena are the financial problems associated with the imprisonment of individuals.

Persons released from the service of an incarceration sentence (but also from custody or other correctional or treatment providing facility) are a group of people who are prone to social exclusion. Possible reasons may include, for example:

- social prejudice not only towards the convicted individuals but also to their families and close relatives (the children often suffer the most),

- stigmatization in connection with the imprisonment (the label of a criminal) which is reflected in the willingness of employers to recruit persons with criminal record,

- loss of social ties (not only with the family but also with the community where the individual lives),

- loss of social skills, including work habits,

- abuse of alcohol and other drugs,

- inability to find an adequate job and keep it (Mares /2000/ notes that marginalization in the labour market is one of the basic current forms of social exclusion),

- the risk of poverty due to indebtedness, loss of job,

- reduction of the level of housing, living in excluded areas (ghettos),

- the issue of acquired helplessness, etc.

For the purposes of this paper, social exclusion is understood as the process by which individuals or groups of people are, for reasons beyond their control, forced to the margins of society and given more difficult or limited access to resources and opportunities (particularly employment, housing, social protection, health care and education; Social Inclusion Strategy 2014-2020, 2014, online, Mareš, Sirovátka, 2008). As we have indicated above, social exclusion is associated with inequality, whether based on the distribution of wealth, on gender, or on ethnic, cultural or religious differences (Mareš, Sirovátka, 2008).

According to Mareš (2000), social exclusion has since time immemorial been a mechanism of social control under which unwanted or nonconformist individuals were pushed to the margins of society (marginalization) or right outside of it (exclusion). Social exclusion also served as a "tool for promoting a shared identity, internal cohesion and integrity" (Mareš, 2000, p. 272). Conversely, at present, social exclusion is understood mostly as a threat to the integrity and cohesion of the society (Mareš, Sirovátka, 2008). Among the main indicators of social exclusion, there are poverty, material deprivation and low work intensity. In addition, these indicators serve as indices of the risk of poverty or social exclusion. (Social Inclusion Strategy 2014-2020, 2014, online).

Social exclusion is linked to substance abuse, especially alcohol, and the issues of gambling. Generally, one of the characteristic traits of citizens living in excluded localities is low education (or low value ascribed to education), which is reflected in employability. Another problem is the phenomenon of hereditary unemployment, as the young generation does not find working habit models in their parents and their reliance on the welfare state becomes a standard (in our practical experience, we are soon going to be receiving the third generation of people who have never worked to serve sentences of incarceration). Other phenomena to be classified as socially pathological include prostitution or crime. 


\section{The Prison System in the Czech Republic}

The Prison Service of the Czech Republic was established by Act no. 555/1992 Coll., On the Prison Service and Judicial Guard of the Czech Republic (as of January 1, 1993). The legislation governing the enforcement of custody and service of incarceration sentence has taken into account the elements of demilitarization and humanization of the prison system of our country as of January 1, 1994; the new legislation was based on the respect for fundamental human rights, personal dignity and the provision of suitable material conditions. The Prison Service belongs to the justice department, regulating the service of incarceration sentence, enforcement of custody and security detention.

As to August 26, 2015, there were 20,346 imprisoned people in the Czech Republic (see Table no. 1). The number of prisoners continues to rise. The saturation of incarceration enforcement facilities currently lies at $103.06 \%$ (18,348 convicts). The enforcement of custody counts 1,944 charged individuals, security detention enforcement involves 54 inmates. The data are available from the website of the Prison Service of the Czech Republic (Information Service, Quick Facts).

Table no. 1 The numbers of prisoners in the Czech Republic as to August 26, 2015

\begin{tabular}{|l|c|c|}
\hline & Male & female \\
\hline Adult & 18,846 & 1,339 \\
\hline Underage & 101 & 6 \\
\hline Inmates* & 49 & 5 \\
\hline Total & \multicolumn{2}{|c|}{} \\
\hline
\end{tabular}

*security detention

Source: The Prison Service of the Czech Republic, Quick Facts, 2015 [online]

The redress and rehabilitation possibilities of individuals in prison facilities are still under discussion (e.g. Papšo, 2011; Černíková, 2008; Zoubková, 2004). In the Czech prison community, the term "treatment of convicts" is used since the 1990's, having replaced the previously used term re-socialization (re-socialization programs). The treatment of convicts is any activity that is carried out with the convicted inmates in order to fulfil the purpose of incarceration sentence service and at the same time to avoid a deterioration of their physical or mental condition. The treatment includes not only social care, education, re-education, psychotherapy, psychological and medical care, but also visits, exchange of mail or employment of prisoners and it takes into account individual needs and possibilities of the convicts. A specific treatment program, then, contains the defined objectives of affecting the imprisoned individual, the methods of treatment of the convicts, aimed at achieving the goals, and the methods and frequency of assessment.

Currently, the statutory framework recognizes the SARPO tool (a predictive tool for the evaluation of risks and criminogenic needs of the convicts in the form of an electronic program) which has been introduced into prisons since November 1, 2012. Since April, 2013, SARPO has served as a standard tool for creating the so-called Comprehensive Reports - documents that form the basis for each prisoner's treatment program. A treatment program determines the interventions that the convict in question is to undergo within a time period of the incarceration sentence service. Criminogenic risks are 
those variables which have been empirically shown to increase the probability of failure. The result is projected on a four-point scale: low, medium, high and very high risk. (Petras, Hůrka, Drahý, Jiřička, 2015) Depending on the risk a convict's screening results in, he or she is included in the corresponding activities of a treatment program. Three basic programs have been defined: minimal treatment program, standard treatment program and special treatment program; while further outbound treatment program, and the basic motivation treatment program for prisoners refusing to confirm their determined treatment program, have been designed. The assessment of the successfulness of the performance of the treatment program forms a part of the overall assessment of the purpose of the incarceration sentence service.

\section{The Financial Problems Associated with Imprisonment}

The incarceration sentence service (but also the enforcement of custody or security detention) brings many negative phenomena (risky behaviour) which we define as all activities or events that in any way make the penitentiary activity or the fulfilment of penal enforcement purposes difficult or impossible. In the context of negative phenomena, these often include aggression, volitional food rejection, substitutive sexual gratification, drug abuse, possession of illegal items and riots. Prisonization and second life of convicts also belong to this issue. Most of these negative phenomena are designated in practice as so-called extraordinary events, which are subject to reporting duty. One of the negative phenomena that affect not only the convicts as such but also their families and ultimately the state, are financial problems associated with incarceration. These problems could be divided into three basic areas:

1. The financial problems of the convict: the loss of job, the rising indebtedness during the sentence service, the inability to repay debts, the extinction of work habits, the problems with obtaining new employment after the release.

2. Financial burden for the convict's family: the loss of the breadwinner, the financial demands of the sentence service.

3. The financial burden for the state: the cost of the convict in incarceration, the convict's family as a financial burden for the state, eventual unemployment benefits after the release, etc.

The first two areas relate primarily to the convicts and their families. It should be borne in mind that the majority of individuals' possible financial problems greatly affect the financial situation of the whole family. It is mostly men who are in incarceration sentence service or in custody, e.g. as to August 26, 2015, 94 \% of all convicted incarceration sentence serving inmates were men (Prison Service of the Czech Republic, Quick Facts, 2015, online), who are often breadwinners, especially if the wife or partner is on parental leave (or the recipient of the disability and retirement pension). Vast majority of convicts are unable to repay their debts during incarceration sentence service without the help of their families, which can be, for example:

- incurred in connection with the provision of healthcare services and costs of regulatory fees (as of January 1, 2015, the only payments are the regulatory fee of CZK 90.00 for the use of emergency medical services or emergency services in the field of dentistry) and additional charges beyond the public health insurance, - unable to pay court and administrative fees on damages or non-pecuniary damages incurred to the Prison Service during the sentence service, 
- to pay regular and outstanding alimony,

- to pay the cost of sentence service,

- to pay debts incurred prior to the sentencing, etc.

We have often witnessed the convict being sent a property seizure order and finding him or herself in a financial trap that is difficult to solve. In prison, they are referred to specialists who can help them carry out steps, however they need to contact the officers, bailiffs, court etc. on their own therefore, their ability to act quickly and respond flexibly is made difficult. The convicts must exert activity on their own to preserve their autonomy and retain their own responsibility for their actions. An inmate who is not assigned work while serving sentence (whether due to lack of jobs, health status, or the like) and who does not receive financial support sent to prison (payments from the family or pension), are in prison without any financial means whatsoever. These prisoners should be given so-called monthly social packages. Social packages are now provided via so-called social vouchers which the convict may use for CZK 100.00 purchases of personal items from the prison canteen. Official mail of prisoners without funds is sent from prison at its expense (Section 17, Subsection 5 of Act no. 169/1999 Coll.). Of course, these individuals are unable to repay any debts (so they increase greatly over the period of imprisonment).

Incarceration of a person is then economically very expensive for the state. In 2014, the average daily cost per prisoner per $1 \mathrm{OU}$ was $954.00 \mathrm{CZK}$ (i.e. the costs of salaries, insurance, other material expenses, the fund of cultural and social needs). The average daily cost for the whole of the Prison Service per 1 prisoner amounted to 1,221.00 CZK (i.e. the costs of salaries, insurance, other material expenses, the fund of cultural and social needs, capital expenditures and social benefits). Below, Table no. 2 represents the costs spent on prisoners in the years 2011 to 2014. (The Prison Service of the Czech Republic, Statistical Yearbook, 2015, online).

Table no. 2 Daily cost per inmate in CZK

\begin{tabular}{|l|c|c|c|c|}
\hline & $\mathbf{2 0 1 1}$ & $\mathbf{2 0 1 2}$ & $\mathbf{2 0 1 3}$ & $\mathbf{2 0 1 4}$ \\
\hline $\begin{array}{l}\text { Average daily cost } \\
\text { per inmate per 1 } \\
\text { OU }\end{array}$ & 782 & 710 & 1,080 & 954 \\
\hline $\begin{array}{l}\text { Average daily } \\
\text { cost for the entire } \\
\begin{array}{l}\text { Prison Service per } \\
1 \text { inmate }\end{array}\end{array}$ & $\begin{array}{c}758 \\
\text { (including } \\
\text { capital } \\
\text { expenditure) }\end{array}$ & $\begin{array}{c}919 \\
\text { (including capital } \\
\text { expenditure and } \\
\text { social benefits) }\end{array}$ & 1,319 & 1,221 \\
\hline
\end{tabular}

Source: The Prison Service of the Czech Republic, the Statistical Yearbook of the Prison Service of the Czech Republic for 2014, 2015

\section{Possibilities of Mitigating the Negative Phenomena Associated with Incarceration}

Individuals released from service of sentence, enforced custody, institutional care (e.g. from educational establishments), but also from curative facilities may be at risk of social exclusion. Negative phenomena associated with incarceration include in particular loss of employment, family disintegration, the loss of social circle contacts, establishment of contacts to the criminal/prison subculture, the inability to integrate back to life in case of the long-term incarcerated, stigma and 
prejudice not only towards the individual, but also to his or her family, inability to repay debts, etc. The financial problems associated with incarceration are one of the possible reasons for (social) exclusion - the individuals released from service of sentence do not have jobs, often have debts (incurred prior to imprisonment but also due to the intensified inability to pay the sentence service enforcement costs and court proceedings), lose their housing due to the disintegration of family or due to the inability to keep their housing during the enforcement of sentence. These factors can be mitigated by greater emphasis on retraining and employment of people (both serving sentence and released), by intervention of post-penitentiary care agents, by the existence of various projects or by imposing alternative sentences.

The goal of post-penitentiary care is the reintegration of the individual into society. The agents of post-penitentiary care include for instance the social worker operating in prison to provide convicts advice and assistance related e.g. to the solution to their debt problems, the mediation of at least temporary housing after release, etc. Social workers in prisons are not typical operators of post-penitentiary care, they rather form a part of penitentiary care, but they do have a significant impact on the individual's first days after release.

An important agent of post-penitentiary care is the social curator. The services offered or mediated by the social curator for adults include assistance in finding housing and employment, mediation of contact with the family, debt solutions, etc. Financial, housing and employment problems are some of the most common problems encountered by the individuals released from service of sentence (Netík, Netíková, 1994). After the fulfilment of legal conditions, the clients may be granted the assistance in material need by the Labour Office of the Czech Republic - the so-called Extraordinary immediate assistance due to the threat of a person's social exclusion. The assistance can be provided up to $1,000.00 \mathrm{CZK}$. The sum of the assistance must not exceed the amount 13,640.00 CZK (four times the subsistence level of an individual) within one calendar year. Other agents of post-penitentiary care include non-governmental non-profit organizations that provide services particularly in the area of basic needs, such as food, accommodation, and consulting. A limit of post-penitentiary care can be to some extent found in its unsystematic organization, varying quality or the very regional availability of social services. Also, the use of these services is voluntary; no convict released from sentence services has to use any of the offered services, whether they need them or not.

The possible social failure of an individual may be caused by the person's inability to find adequate employment after release. It is important that prisons and above all the Educational Training Centres in prisons try to adapt the offer of training courses and apprenticeships to the requirements of the labour market or to specific regional circumstances. In some prisons, closer cooperation with employment agencies or non-profit organizations that help displaced persons in search of employment or are themselves providers of employment opportunities or provide financial advice is already in progress.

Also, specific projects aimed at better reintegration of persons after their release from prison may be of assistance. Since July 1, 2015, the pilot project "Probation House" has started under the Probation and Mediation Service of the Czech Republic and the Nové šance, z.s. (listed society New Chances), which should form an intermediate stage between prison and free life. The courts could order a stay within the Probation House as part of conditional release. The aims and objectives of 
the project are mainly: to support and facilitate people released from sentence service and protect the society against recidivism and homelessness. So far, one Probation House has been opened in Ostrava with a capacity of 20 inmates. It is essential that both professional and general public are in favour of the existence of such projects and that there is a continuous (especially financial) support from the state.

The negative effects of serving an incarceration sentence, including financial ones, may be partly mitigated or eliminated by alternatives penalties, especially with perpetrators of less serious crimes. An alternative penalty is understood as a non-incarcerating penalty sentence; the alternative must not include any loss of freedom, and the perpetrator must be able to comply with the conditions (e.g. in case of fines; Černíková, 2008). The alternatives may include for instance the institute of settlement, suspended sentence and suspended sentence with supervision, community service or house arrest. The benefits of these alternatives can be seen not only from the humanitarian, but especially from the economic (non-custodial sentence service is much cheaper than incarceration, the family of the incarcerated do not become a financial burden to the state) and pragmatic point of view (alternative sentencing helps offenders maintain social status, including employment).

\section{Conclusion}

The incarceration of a person is financially demanding for the convict, his or her family, but also for the state. The sentence serving convicts often have to repay debts and damages from crime, while the wage earned in an assigned job, if possible, usually only covers basic needs and payments (reimbursement of sentence enforcement costs, alimony, purchases in prison shops, etc.). Yet, vast majority of convict debts are growing, many of them amounting to hundreds of thousands of Czech Crowns (the cost of legal proceedings, costs of custody and incarceration, outstanding alimony, seizure of property, etc.). After release from prison, the individual may have trouble finding a job or resume their work habits. The financial problems of the individuals often affect the whole family, who become a financial burden to the state. For the state, the incarceration of a person is equally costly, due to the imprisonment alone or indirectly due to the social assistance provided to the individual after release before they resume activity on the labour market.

As a result of imprisonment, the individual and his or her family may be at risk of social exclusion. The negative phenomena caused by incarceration can be eliminated during the post-penitentiary care by the emphasis on retraining of individuals to help them find adequate employment while serving their sentence but mainly after release, or by the use of alternative sentences which do not involve incarceration. We believe that in this area, there are still limitations - legislative, financial, systemic, and in public opinion. The issue of social exclusion of persons released from prison or other facilities and its possible prevention should become a topic for exploration of social pathology, criminology and related sciences (e.g. Bělík, 2015); attention should turn to the possibility of mitigating the negative phenomena associated with incarceration and to the possibility of preventing social exclusion. 


\section{References}

Bělík, V. (2015). Výzkumné výzvy v sociálně pedagogických tématech. [Research Challenges in Socio-Educational Topics]. In S. Hoferková (Ed.), ACTA SOCIOPATHOLOGICA II (pp. 20-33). Hradec Králové: Gaudeamus.

Černíková, V. et al. (2008). Sociální ochrana: terciární prevence, její možnosti a limity. [Social Protection: Tertiary Prevention, Its Possibilities and Limits]. Plzeň: Vydavatelství a nakladatelství Aleš Čeněk, s.r.o. [Editing and Publishing House Aleš Čenek, Ltd.].

Mareš, P. (2000). Chudoba, marginalizace, sociální vyloučení. [Poverty, Marginalization and Social Exclusion]. Sociologický časopis [Czech Sociological Review], 36(3), pp. 285-297.

Mareš, P., Sirovátka, T. (2008). Sociální vyloučení (exkluze) a sociální začleňování (inkluze) koncepty, diskurz, agenda. [Social Exclusion and Social Inclusion: Concepts - Discourse-Agenda]. Sociologický časopis [Czech Sociological Review], 44(2), pp. 271-294.

Netík, K., Netíková, D. (1994). Vybrané kapitoly z forenzní psychologie pro právníky. [Selected Chapters from Forensic Psychology for Lawyers]. Prague: Charles University, Institute of Criminology of the Law Faculty of Charles University.

Papšo, P. (2011). Resocializácia odsúdených vo výkone trestu odňatia slobody. [Re-socialization of Convicts Serving Incarceration Sentence]. Banská Bystrica: Matej Bel University in Banská Bystrica, Faculty of Education.

Petras, M., Hůrka, J., Drahý, F., Jiřička, V. (2015). Hodnocení kriminogenních rizik odsouzených (diskusní panel). [Assessment of Criminogenic Risks to Convicts (panel discussion)]. In S. Hoferková, T. Raszková (Eds.), III. Kriminologické dny. [Criminological Days]. Proceedings of the Conference Held in Hradec Kralove on January 19 and 20, 2015 (pp. 395-407). Hradec Králové: Gaudeamus.

Scheinost, M. et al. (2013). Teoretické a trestněpolitické aspekty reformy trestního práva v oblasti trestnich sankcí I. Trestní sankce a jejich odraz v praxi, tisku a v názorech verejnosti. [Theoretical and Punitive Policy Aspects of the Reform of Criminal Code in the Field of Criminal Sanctions I. Criminal Sanctions and Their Reflections in Practice, Press and Public Opinion]. Prague: The Institute of Criminology and Social Prevention.

Strategie sociálního začleňování 2014-2020. [Social Inclusion Strategy 2014-2020]. [online]. Accessed $16^{\text {th }}$ August 2015. http://www.mpsv.cz/cs/17081.

The Prison Service of the Czech Republic. (2015). Statistical Yearbook of the Prison Service of the Czech Republic for 2014, ref. no. VS 58/007/008/2015-50/SPR/430. Prague: The General Directorate of the Prison Service of the Czech Republic.

The Prison Service of the Czech Republic. Quick Facts. [online]. Accessed $16^{\text {th }}$ August 2015. http:// www.vscr.cz/generalni-reditelstvi-19/informacni-servis/rychla-fakta/.

Zoubková, I., Moulisová, M. (2004). Kriminologie a prevence kriminality [Criminology and Crime Prevention]. Prague: Armex. 


\section{Authors}

Mgr. et Mgr. Tereza Raszková

Faculty of Education, University of Hradec Králové

Department of Social Pathology and Sociology

Rokitanského 62, 500 03, Hradec Králové, Czech Republic

Tereza.Raszkova@uhk.cz

Mgr. et Mgr. Stanislava Hoferková, Ph.D.

Faculty of Education, University of Hradec Králové

Department of Social Pathology and Sociology

Rokitanského 62, 500 03, Hradec Králové, Czech Republic

Stanislava.Hoferkova@uhk.cz 